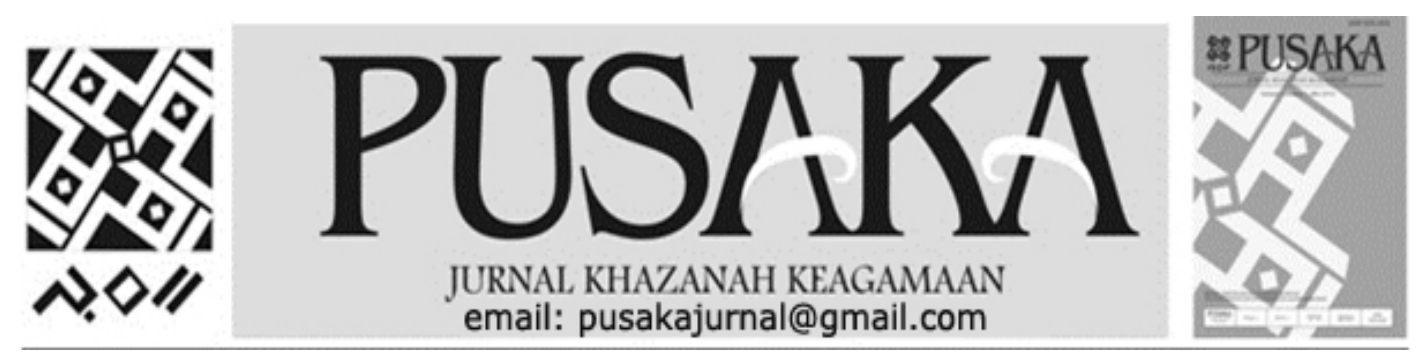

\title{
Peran Orang Arab Dalam Pendidikan Keagamaan di Kabupaten Maros
}

\author{
The Role of Arabs in Religious Education in Maros District
}

\section{Wardiah Hamid}

Balai Penelitian dan Pengembangan Agama Makassar

Jl.A.P.Pettarani No.72 Makassar. Telp:0411-452952

Email: wardiahlitbang@yahoo co.id.

\begin{tabular}{|c|c|}
\hline $\begin{array}{c}\text { Info } \\
\text { Artikel }\end{array}$ & Abstract \\
\hline $\begin{array}{c}\text { Diterima } \\
21 \\
\text { Juni } \\
2017 \\
\text { Revisi I } \\
7 \\
\text { Agustus } \\
2017\end{array}$ & $\begin{array}{l}\text { Sejarah telah mencatat bahwa pembawa Islam ke wilayah Nusantara adalah para } \\
\text { pedagang dan mubalig dari negeri Arab. Mereka sangat berjasa dalam } \\
\text { penyebaran dan pengembangan agama Islam di Indonesia. Kemudian } \\
\text { membentuk pemukiman di sepanjang wilayah di Nusantara. Keberadaan mereka } \\
\text { di Sulawesi Selatan begitu urgen untuk ditelusuri. Penelitian ini akan mencoba } \\
\text { untuk mendeteksi keberadaan mereka di kabupaten Maros. Untuk itu rumusan } \\
\text { masalahnya adalah bagaimana gambaran persebaran keturunan orang Arab } \\
\text { kabupaten Maros dan bagaimanasistem kelembagaan yang dibangun oleh } \\
\text { keturunan Arab. Pendekatan yang dilakukan dalam penelitian ini adalah kualitatif } \\
\text { deskriftip. Hasil dari penelitian ini menunjukan keturunan Arab yang masih eksis } \\
\text { sampai sekarang diantaranyAl Hamid, Al Idrus, Al qadri, Al Habsyi, bin Syihab, } \\
\text { Al Mahdali, bi Faqih, Alwi dan Aidit, Assaggaf, Aidit, Al Idrus.Dan beberapa } \\
\text { diantara mereka mengelola lembaga Pendidikan keagamaan di Sulawesi Selatan. } \\
\text { Di Maros ada tarekat Khalwatiyah Yusuf mursyidnya adalahn marga Assegaf } \\
\text { yang tetap eksis sampai sekarang. } \\
\text { Kata Kunci : Persebaran keturunan Arab, Lembaga Pendidikan. }\end{array}$ \\
\hline $\begin{array}{c}\text { Revisi II } \\
28 \\
\text { September } \\
2017 \\
\text { Disetujui } \\
19 \\
\text { Oktober } \\
2017\end{array}$ & $\begin{array}{l}\text { History has noted that the bearer of Islam to the archipelago is the traders and } \\
\text { mubalig from the Arab country. They are very meritorious in the spread and } \\
\text { development of Islam in Indonesia. Then formed settlements along the territory } \\
\text { of the archipelago. Their existence in South Sulawesi is so urgent to be explored. } \\
\text { This research will try to detect their presence in Maros district. For that problem } \\
\text { formulation is how the description of the distribution of descendants of Arabs } \\
\text { Maros district and how an institutional system built by the Arab descendants. } \\
\text { The approach taken in this research is qualitative deskriftip. The results of this } \\
\text { study show that Arab descendants still exist today among them, Hamid, Al Idrus, } \\
\text { Al qadri, Al Habsyi, bin Syihab, Al Mahdali, Bi Faqih, Alwi and Aidit, Assaggaf, } \\
\text { Aidit, Al Idrus. And some of them manage institutions Religious education in } \\
\text { South Sulawesi. In Maros there is the Khalwatiyah tarekat Yusuf mursyidnya is } \\
\text { the Assegaf clan that still existed until now. } \\
\text { Keywords: Spread of Arab descent, Educational Institution. }\end{array}$ \\
\hline
\end{tabular}




\section{PENDAHULUAN}

Kebiasaan untuk meninggalkan kampung halaman yang dilakukan oleh sebahagian kaum Hadramaut menjadi hal menarik untuk dicermati. Mereka tersebar diberbagai tempattempat di penjuru negeri. Apakah berprofesi sebagai juru dakwah dan pedagang. Di tempat mereka bermukim berusaha menjalin tali persaudaraan dengan cara kawin mawin dengan penduduk lokal ataupun mengadakan pendekatan dengan kaum aristokrat muslim sehingga mampu menduduki posisi penting di tengah masyarakat.

Para pedagang Arab dari Hadramaut adalah orang-orang pertama yang menyebarkan Islam ke Indonesia. Arab Hadramaut itu sudah sampai ke pulau-pulau di Nusantara sejak abad pertama hijriyah (ketujuh Miladiyah), atau tepatnya pada dasawarsa kedelapan dari abad itu mereka datang untuk mencari rezeki, mengingat iklim negerinya dan kondisi hidup di Arabia Selatan agak sulit. Dalam waktu singkat, Arab Hadramaut itu berubah menjadi da' $i$ Islam ke seluruh negeri yang mereka singgahi, baik dakwah bil lisan maupun bil hal, sampai ke pesisir pantai Timur Afrika, India dan Indonesia (al Alusi, 1992: 20).

Mencari keuntungan ekonomi menjadi alasan utama bagi orangorang Arab, khususnya komunitas Hadrami, berimigrasi ke Nusantara. Pada abad ke-19, pengaruh komunitas Arab semakin intensif ketika jumlah mereka makin meningkat. Mereka membangun perkampungan di jalur-jalur perdagangan di Nusantara. Aceh menjadi perkampungan Arab pertama, dari sana mereka bergerak ke Palembang dan Pontianak, kemudian Batavia dan pusat-pusat perdagangan penting di Jawa Cirebon, Tegal, Pekalongan, Surabaya, dan juga Madura (Burhanuddin, 2012: 101).

Ketika mereka berbaur dengan masyarakat lokal tradisi yang mereka bawa dari kampung halamannya menjadi ciri khas tersendiri, sebahagian tetap terpelihara dan ada pula yang usang oleh pergeseran waktu dan tempat ataupun tetap bertahan hingga sekarang. Tetapi yang pasti sebagian diantara mereka membawa misi dakwah di bumi Nusantara hingga membentuk lembaga Pendidikan formal maupun non formal.

Ada beberapa faktor yang menfasilitasi kaum sayid Hadramaut untuk bermukim di banyak kawasan di Samudera Hindia dan memudahkan mereka mendaki tangga social. Pertama, kemampuan bepergian dimudahkan oleh jaringan perdagangan. Kedua hubungan intelektual mereka dengan jaringan ulama yang menjadikan mereka bagian dari sebuah komunitas intelektual internasional, sehingga kadar keulamaan mereka mudah dikenali. Dalam hal ini, faktor terpenting adalah keanggotaan mereka dalam mazhab Syafi'i yang mendominasi pesisir Samudera Hindia. Ketiga, penguasaan terhadap Bahasa dan sastra Arab menjamin penghormatan para penguasa kepada mereka. Keempat karakter kosmopolitan dari lokalitas tempat mereka berimigrasi memudahkan mereka berintegrasi dengan masyarakat tanpa harus dicap sebagai golongan asing (Berg, 2010: xxxixxxii). Mereka mampu cair dengan 
masyarakat lokal dengan memainkan peranannya sebagai komunitas muslim di Nusantara tanpa ada jurang pemisah antara masyarakat pribumi. Walaupun mereka mampu berbaur sebahagian besar dari komunitas Arab ini tetap mempertahankan kemurnian silsilah mereka.

Dengan struktur berbasis silsilah, posisi para sayid Hadramaut menjadi begitu penting seperti halnya para Sultan Melayu, mereka juga memiliki silsilah yang justru lebih pretisius karena menyambung kepada nabi. Sistem kekeraban inilah yang memungkinkan para Sayid Hadramaut mendekati para penguasa dan memberikan mereka hadiah berharga dalam bentuk silsilah melalui proses perkawinan. Dengan kata lain, sistem kekerabatan yang lazim di Nusantara kala itu mempercepat proses asimilasi para Sayid Hadramaut dan memudahkan mereka memanjat tangga sosial melalui perkawinan yang kemudian menghasilkan generasi kedua sayid Hadramaut. Generasi kedua inilah yang kemudian memiliki karakter dasar hibrida (Berg, 2010: xxxiii). Meskipun tidak bisa dipungkiri bahwa pendatang dari Arab yang non sayid mampu memasuki ruang-ruang sosial di Nusantara dan membentuk komunitas muslim Arab dan mampu memberikan kontribusi yang cukup mewarnai dinamika sosial ekonomi, politik dan pendidikan di nusantara

Di masa sekarang ini menjadi hal yang patut untuk disorot dalam kacamata pendidikan keagamaan khususnya di Sulawesi Selatan dengan mengambil titik-titik komunitas ini di Kabupaten Maros. Dalam hal kontribusi mereka sebagai bagian komunitas Arab dan sebagai warga Indonesia yang ikut mencerdaskan anak bangsa.

Berdasarkan latar belakang di atas, permasalahan yang diangkat dalam penelitian ini adalah

1. Bagaimana gambaran persebaran keturunan orang Arab di Maros?

2. Bagaimana sistem kelembagaan yang dibangun oleh keturunan Arab di Maros?

Penelitian ini bertujuan menjawab permasalahan di atas

1. Mengetahui gambaran persebaran keturunan orang Arab di kabupaten Maros.

2. Mengetahui sistem kelembagaan yang dibangun orang Arab di kabupaten Maros.

Hasil penelitian ini diharapkan bermanfaat bagi:

1. Jajaran Kementerian Agama dan instansi lainnya yang berkepentingan sebagai data keagamaan yang dapat dijadikan dasar pertimbangan dalam pengambilan kebijakan pembangunan di bidang agama;

2. Para akademisi, pencinta ilmu, serta pihak-pihak lainnya sebagai informasi faktual untuk kepentingan pengembangan pengetahuan.

3. Kepustakaan masyarakat sebagai pengayaan khazanah keagamaan yang dapat berguna sebagaiu acuan moral dan intelektual.

\section{Kajian Teori}

Kajian teori yang dibangun adalah teori perubahan Ibnu Khaldun. Teori ini mencakup dua bentuk organisasi organisasi sosial yang berlawanan nomaden dan menetap. Teori ini mencoba 
menerangkan kesuksesan orang Badui merobohkan sejumlah peradaban di Afrika (Lauer, 1977 :44).

Orang Arab ditempat asalnya adalah padang pasir, mencari nafkah dengan jalan memelihara ternak seperti beri-beri, kambing dan unta. Tetapi ketika sampai ke Nusantara kehidupan itu kemudian berubah mereka berprofesi sebagai pedagang dan juru dakwah. Cara berdagang mereka lakukan untuk mencari nafkah sebagai dan sebagai bentuk untuk bertahan hidup. Dan berprofesi sebagai juru dakwah adalah salah satu strategi memberikan penerangan agama kepada penduduk lokal. Cara ini begitu berkesan bagi penduduk lokal sehingga mereka bisa diterima hingga terjadi kawin mawin dengan wanita pribumi.

Teori lain yang mendukung penelitian tentang keturunan Arab di Nusantara adalah teori jaringan yaitu pemusatan perhatiannya pada struktur sosial mikro dan makro. Artinya bagi teori jaringan, aktor mungkin saja individu tetapi mungkin juga kelompok. Hubungan bisa terjadi ditingkat struktur sosial skala luas maupun yang lebih kecil. Hubungan ini berlandaskan gagasan bahwa setiap aktor (individu atau kolektivitas) mempunyai akses berbeda terhadap sumber daya yang bernilai (kekayaan, kekuasan, informasi) (Goodman, 2007 : 383).

Jaringan atau hubungan antar orang Arab dan orang pribumi mempunyai hubungan dan ikatan kuat. Jaringan ini mempunyai ikatan kuat yang memotivasi lebih besar untuk saling membantu dan lebih cepat untuk saling memberikan bantuan. Demikian pun yang terjadi pada kasus jaringan orang Arab dan pribumi, betapa kuat kuat jaringan yang terbentuk hingga diantara mereka saling memberikan bantuan disetiap aspek kehidupan sosial religi ataupun pendidikan. Orang Arab yang datang ke Indonesia membangun lembaga formal maupun non formal disetiap tempat yang menjadi konsentrasi pemukiman mereka. Mereka saling bergantung di dalalm ikatan jaringan itu dan saling menguntungkan. Dengan terbentuknya lembaga pendidikan keagamaan formal maupun non formal ikut memberi andil keberagamaan yang solid mencerdaskan penduduk pribumi khususnya pemahaman agama. Pola hubungan ini memberikan ruang bagi orang Arab untuk mendaki tangga sosial di masyarakat dengan kedudukan mubaligh, ustadz ataupun pemimpin tarekat.

Penelitian ini dimulai dengan tahapan pertama interview, teknik ini adalah wawancara pihak-pihak yang terkait dengan objek penelitian, diantaranya keturunan Arab Di Sulawesi Selatan khususnya yang ada di Kabupaten Maros. Kedua penelusuran dokuman seperti kajian pustaka dan literature yang terkait dengan orang Arab di Maros. Ketiga observasi dilakukan pengamatan secara mendalam komunitas Arab di Maros dan tempat lain yang terkait dengan keturunan Arab di Maros.

\section{Orang Arab di Maros}

Keberadaan orang Arab di Maros tidak bisa dilepaskan dengan Tarekat khalwatiyah Yusuf sebagai tarekat yang dikembangkan oleh orang Arab ber-fam Assaggaf. Ketika Syekh Yusuf berada di 
Banten, beliau mengirim salah satu muridnya yang sangat pintar dan dipercaya untuk mengembangkan misi dakwah ke Sulawesi yang dikenal dengan nama Tuang Rappang berasal dari Rappang yang berasal dari keluaga kaya raya. Beliau adalah seorang tuna netra tetapi sangat mendalami ilmu Tarekat dan Syariah. Tuang Rappang mengajarkan tarekat Khalwatiah Yusuf di daerah Gowa dan mampu menarik para bangsawan Gowa untuk masuk dalan tarekat ini. Keberadaan tarekat ini tidak hanya dianut di dalam istana, tetapi juga ke tengah masyarakat. Akhirnya, beliau meninggal di Rappang kemudian mayatnya diusung sampai ke Gowa. Makamnya berada di dalam lokasi pemakaman Syekh Yusuf.

Sultan Abdul Jalil (1677-1709) yang menjadi raja Gowa ke 19 merupakan pengikut setia tarekat Khalwatiyah Yusuf. Pengaruh tarekat ini sampai ke daerah Bontoala yang merupakan daeah kekuasaan Gowa, dan sebuah pesantren berdiri tahun 1635 yang di pimpinoleh Sayed Ba' Alwy Bin Abdullah Thahir Tuang Karama'. Pesantren ini menjadi lembaga yang terhitung sebagai Pendidikan Islam pertama di Sulsel. Tumbuh Bersama dengan perkembangan dengan penyebaran tarekat Khalwatiyah Yusuf (Hamid, 2005). Beliau dikuburkan di Barang Lompo yang menjadi tempat persinggahan untuk pertama kalinya di daerah Sulawesi Selatan. Ia kemudian menikah dengan anak Sultan Abdul Jalil bernama Sitti Fatimah. Dari perkawinan ini orang Arab (kaum Hadramaut) masuk dalam lingkup istana.
Anak hasil perkawinan tersebut dikenal oleh penduduk lokal sebagai integral dari kelompok mereka saat yang sama, mereka juga menjadi bagian dari jaringan diaspora Hadrami yang jauh lebih luas dari lokalitas mereka. Hal ini berarti walaupun mereka bertindak dalam kapasitas lokal, mereka juga dengan mudah dapat merantau dan menjalin hubungan dengan jaringan diaspora Hadrami, sehingga menghasilakan tingkat mobilitas yang cukup tinggi. Perairan Nusantara dengan segala kecairannya, membuka peluang bagi artikulasi identitas tak terhingga, yang memungkinkan diaspora Hadrami menjadi pribumi dan disaat yang sama menjadi bagian dari komunitas diskursif yang lebih luas (Berg, 2010: xxxiii).

Dari perkawinan ini lahirlah Sayed Husain Assaggaf ke Gowa dikuburkan di dekat masjid tua Katangka. Sayed Husain Assaggaf melahirkan Sayid Abdul Gaffar Waliuddin Assagaf diangkat menjadi qahdi ditahun (1769-1814) dan diangkat menjadi khalifah tarekat Khalwatiyah Yusuf. Sayed Abdul Gaffar Waliuddin Assaggaf menggantikan mertuanya yaitu Muhammad Rajab di tahun 1718 qadhi ke tiga di Gowa. Sayed Abdul Gaffar Waliuddin Assaggaf sebagai khalifah tarekat Khalwatiyah sekaligus menjadi qadhi keempat di Bontoala. Dimasanya, penyebaran tarekat ini ke wilayah Bugis semakin meluas. Sayyed Abdul Gaffar Waliuddin Assaggaf menerima tarekat ini dari Syekh Abu Abdul Majid Nuruddin bin Abdullah menerima tarekat dari Syekh Abu Saad Muhammmad Fadhil dan beliau menerima juga dari Syekh Abu Fath 
Abdul Basyir al-Dariri al-Rappani alKhalwatiy (Hamid, 2005:214). Sumber tutur masyarakat menyebut Tuang Rappang adalah orang Arab meskipun dia disebut orang Rappang hanya untuk memberi legitimasi tempat mukimnya. versi lain juga menyebut Syekh Yusuf adalah seorang Sayid.

Dari Sayyed Abdul Gaffar Waliuddin Assaggaf lahir putranya Sayid Muhammad Zainuddin Assaggaf, kemudian menjadi qadhi ke-5 di Bontoala sekaligus qadhi di Maros dan murysid tarekat Khalwatiyah Yusuf di Maros. Atas permintaan masyarakat Maros yang datang ke Bontoala berguru tarekat ini maka mereka Muhammad Zainuddin Assaggaf memenuhi permintaan tersebut.

Menurut Danial Asseggaf:

"Dari garis nasab dari laki-laki tetap dipertahankan garis keturunannya. Dalam rumpun ini ada marga diantaranya AlHamid, Al-Idrus, Al-Qadri, AlHabsyi, Bin Syihab, Al-Mahdali, Bil Faqih, dengan satu jalur nenek moyang yang sama. Ainu Zainal Arbath melahirkan Alwi dan Aidid, semua marga Assaggaf, Aidid silsilahnya bertemu diatas Al Idrus dan Al Hamid tidak bertemu di bawah tetapi pasti bertemu diatas. Kalau berbicara masalah darah maka, kami akan cenderung ke Timur Tengah sebagai tempat asal muasal nenek moyang kami tetapi, dalam rentang waktu yang cukup lama berbaur dengan masyarakat lokal sehingga budaya Bugis Makassar seakan-akan kami memikul budaya mereka.
Contohnya masalah badik yang merupakan budaya Bugis Makassar sering masyarakat sekitar datang pada kami berkonsultasi tentang bagaimana perihal badik tersebut. Saya termasuk pemerhati kearifan lokal seperti pappaseng toriolo, yang sarat dengan filosofi-filosofi hidup. Makanya dalam keluarga kami Bahasa Bugis tetap kami pergunakan dalam bahasa sehari-hari. Hal seperti ini saya rasakan bagaimana mudahnya membaca naskah berbahasa Bugis tapi tulisannya adalah Arab. Sehingga saya memberikan motivasi kepada generasi kami untuk bisa membaca naskah yang tulisannya Arab tetapi berbahasa Bugis. Kami sudah bergaul dengan masyarakat kampung sehingga kekentalan budaya lokal betul-betul terserap dalam kehidupan sehari-hari. Karena kekentalan budaya lokal ini sehingga generasi saat ini masih banyak yang tidak tahu bahwa nenek moyangnya adalah orang Arab. Dan ketika bertanya kepada mereka dari mana mereka berasal maka jawabannya adalah tidak tahu. Sehingga masalah Pendidikan agama sebahagian sudah tidak kental lagi dalam masalah keaagamaan."

\section{Sistem Lembaga Pendidikan Keagamaan \\ Penekanan pada pada tasawuf dan metode dakwah secara damai inilah yang mewarnai secara turun}


temurun sebagaian kaum Alawiyin dimana pun mereka berada sampai pada masa sekarang ini. Kiranya sikap ini diambil, disamping kecendrungan kesufian memang mempromosikan prinsip cinta kasih dan anti kebencian, akibat kenyataan bahwa peperangan-peperangan yang melibatkan kaum Alawiyin di masamasa sebelumnya ternyata hanya menyisakan kerugian dan kerusakan. Sebagai gantinya, kelompok ini percaya bahwa mengutamakan cinta kasih, kedamaian dan sikap-sikap kelembutan, justru akan menjadi cara efektif untuk menarik hati banyak orang, bahkan juga hati musuh dan orang-orang jahat di tengah-tengah masyarakat (Kazhim, 2012 :7).

Sehingga tarekat Khalwatiyah Yusuf pun berkembang di Maros dan dilanjutkan oleh keturunan beliau. Tarekat ini cukup terbuka bagi siapa saja yang ingin datang belajar di tempat itu tepatnya di daerah Kassi Labuang Kabupaten Maros. Dikembangkan oleh Sayed Abdul Muthalib Puang Lallo (1925) beliau merupakan ulama yang pernah belajar ke pulau Salemo Bersama Puang Ramma, Puang Sese. Ayahanda Rauf Asseggaf dosen UMI belajar kepada Puang Walli, sebelum ke Salemo beliau berguru kepada KH M. Asaf rumahnya di Pappandangan poros Tanralili Maros. Setelah dari Salemo beliau mengaji lagi ke gurunya KH. M. Asaf dan H. Puang Tobo di Maros. Kemampunnya dalam ilmu falak dengan menafsirkan akan terjadi gerhana matahari di tahun 1983. Dua tahun sebelumnya, beliau mengajarkan salat gerhana di masyarakat dan memanggil murid-muridnya di sekitar Masjid Al-Manar.
Pengumuman dari pemerintah akan terjadi gerhana matahari satu minggu sebelumnya tetapi, meerka sudah mengetahuinya dan sudah ada persiapan untuk melaksanakan salat gerhana matahari. Setelah itu beliau juga menafsirkan setelah terjadi gerhana matahari di Indonesia maka akan terjadi gerhana lagi di tanah di Timur Tengah.

Menurut Danial Asseggaf:

"Puang Lallo mengetahui gerhana bulan pada tanggal 30 September 1982 setelah solat magrib,. Pada saat itulah dimulai melaksanakan salat tepat jam 02.00 koma 3 detik. Barulah kentara gerhana matahari lima menit lewat beberapa detik lamanya terjadi gerhana tersebut. Catatan khususnya juga akan terjadi pada tanggal 14 Desember 1983 Masehi gerhana matahari terjadi di Mekah. Setelah beberapa tahun kemudian beliau tidak melakukan hitung hitungan ilmu falak ini, disebabkan alat-alat deteksi fenomena gerhana sudah lebih berkembang lagi“.

Beliau mendirikan sekolah Arab di Kassi di Langgar Al-Manar. Sebelum berubah menjadi masjid masih berbentuk Langgar dan menjadi pusat sekolah Arab. Sekolah Arab ini berdiri setelah Indonesia merdeka. Puang Lallo juga bergabung dengan DDI Pappadangan tahun 1955 setelah itu dipindahkan ke jalan Takwa daerah Kota Maros.

Beberapa daerah yang menjadi basis perkembangan tarekat ini sampai sekarang berada di daerah 
Kassi ada sekitar 30 rumah dalam komunitas Arab. Tarekat ini juga berkembang di wilayah Maros Utara Tambua Maros di bawah Khalifah Sayyed Zainal Abidin Assagaf ( Puang Awing), Sayyed Tajuddin Assagaf Puang Taju. Kemudian ke wilayah Pangkep Segeri dan wilayah Palanro Cilallang Barru.

Menurut Darmawijaya dalam bukunya "Nikmatnya Tasawuf Mengupas kisah Sukses Ulama Tasawuf dalam Islamisasi Nusantara", para murid tarekat Khalwatiyah ini dibedakan dalam tiga tingkatan, yaitu;

1. Makam bidayah, yaitu tingkatan permulaan. Pada tingkatan ini murid dilatih membaca zikir la ilaha illa Allah, sebanyak 10100-300 kali setiap hari.

2. Makam tawassut, yaitu tingkan khusus, dimana para murid lebih meningkatkan zikirnya dengan membaca Allah Allah sebanyak 40-101-300 kali setiap hari'

3. Makam nihayah, yaitu tingkatan lebih khusus. Tingkatan ini disebut juga dengan tingkatan ahli zikir yang hanya diamalkan oleh syekh atau murid yang terpilih. (Darmawijaya, 2008 : 78)

Kitab yang diajarkan dalam tarekat ini berasal dari beberapa tulisan tangan yang diwariskan dari nenek orang tua dan tulisan tangan kumpulan kitab karangan Syekh Yusuf. Dan beberapa peninggalan tarekat seperti tuang Rappang. Tarekat ada amalan umum atau atauran-aturan umum dapat ditemui dalam karangan tarekat. Ada ciri wirid-wirid zikir dengan nama tersendri dari masing-masing tarekat. Apa yang dilakuan ada wirid umum dan khusus. Wirid umum bisa dibaca di tarekat muktabarah dan yang khusus diajarkan guru tarekat masing-masing. Kitab yang umum Ihya Ulumu al-Din, Tanwiru alQulub, Jamiu al-Usul fi Auliya, Awalifu al-Ma'arid, al-Insanu alKamil (manusia Sempurna). Yang khusus tulisan tangan para khalifah yang diwarisi dari turun temurun. Pola pengkaderan untuk diamalkan, dan yang khusus meningkatkan diri secara sungguh dan seorang mursyid mengangkatnya nantinya bisa dari kalangan luar atau keluarga sendiri.

Pengikut tarekat ini umumnya berasal dari masyarakat non Arab. Siapa pun boleh menjadi anreguruta dalam tarekat ini bila memenuhi syarat untuk menjadi anreguru, tetapi sampai sekarang posisi itu tetap dipegang oleh keturunan Assaggaf. Pengikut tarekat ini berkembang dengan menyentuh berbagai lapisan masyarakat. Para pengikut memahami bahwa niat mereka datang untuk belajar dan tanpa undangan tetapi kesadaran sendiri. Intinya murid yang mendatangi guru. Mereka datang dari berbagai daerah di luar Kabupaten Maros seperti Pangkep, Barru, Pinrang Makassar bahkan di luar Pulau Sulawesi seperti Sorong, Kalimantan, Timika, Jayapura, Manokwari dan Kupang. Di masa Sayeid Abdul Muthalib (Puang Lallo), wilayah tarekat ini hampir mengusai wilayah Maros bagian selatan pusat kota Maros. Di Kassi Labuang menjadi sentra pusat pengajaran tarekat ini dan didirikan Langgar dan sekarang menjadi masjid Al-Manar Labuang. Maros menjadi terkenal dengan pola 
pendidikan agama bercorak tarekat. Disamping tarekat Khalwatiyah Yusuf, berkembang pula tarekat Khalwatiyah Samman. Keduanya berada di kabupaten Maros dengan jarak yang berjauhan. Khalwatiyah Samman berlokasi di daerah Pate'ne Maros dengan mursyid bernama Syekh Andi Sirajuddin puang Tompo dan menyebar diberbagai daerah di Maros seperti pinggiran pesisir pantai Maros disebut kampung Leppangkomai dan Bantimurung, serta Solo Jirang dengan khalifahnya disebut puang Lompo berasal dari masyarakat pribumi. Ketika penulis berada dilokasi Kassi yang menjadi sentral pemukiman komunitas Khalwatiyah Yusuf. Salah satu anggota keluarga Khalwatiyah Samman berkunjung ke daerah itu. Jalinan pertemanan diantara mereka tanpa batas pemisah.

Menurut Rijal Asseggaf:

"Ketika saya menjabat Kepala

Kantor Agama Maros Maudu

Lompo di Patte'ne selalu diadakan tanggal 20 bulan Rabiul awal pertemuan diantara pengikut Khalwatiyah Zaman selalu hadir dan memimpin doa. Imam Masjud Turikale Khalifah Andi Hidayat Puang Rukka senantiasa diundang ke Kassi acara Haul setiap tahun setelah Ramadhan Haul Tarekat Khalwatiyah Yusuf dan Haul Puang Lallo. Acaranya intinya membaca manaqib sejarah hidup Puang Lallo dan perjuangannya demikian juga sejarah Syekh Yusuf dan Sayed Ba Alwy, yang dilaksanakan di Masjid Al-Manar, Tahlilan Khatam Alquran dengan semua orang membaca Alquran sampai khatam, lalu pahalanya dihadiahkan kepada beliau yang dirayakan peringatan haulnya. Pengikutnya diperkirakan sekitar puluhan ribu orang".

Tahun $1802 \mathrm{M}$, tarekat Khalwatiyah Samman masuk di Sulawesi Selatan yang di bawa oleh Syekh Abdulllah Al-Munir yang diterima dari Syekh Abdul Shamad Palembang. Jalur silsilah tarekat ini mempunyai sumber yang sama dengan silsilah Khalwatiyah Yusuf, namun para pengaruhnya tetap mengakui tokoh Syekh Yusuf. Meskipun terdapat perbedaan praktek pada kedua tarekat ini dan menggunakan nama yang sama, namun semuanya mengakui Syekh Yusuf sebagai seorang yang bertaraf wali dan mereka cenderung untuk selalu berziarah ke makamnya setiap saat menurut keperluannya. Keduanya juga bersumber dari silsilah khalifah yang sama, kemudian bercabang dua sesudah khalifah ke-21 dari susunan kekhalifaan yaitu Syekh Qutub Zaman Maulana Affandi Umar alKhalwatiy. Mulai dari khalifah ini bercabang pada Syekh Maulana Sayid Yahya al-Syarwani bagi khawatiyah Yusuf, sedangkan Khalwatiyah Samman turun pada Syekh Muhammad Amir Ummul Khalwatiy. Kedua cabang ini berkembang sendiri-sendiri dan membentuk kekhalifaan masingmasing (Darmawijaya, 2008: 138139).

Menurut Sayed Muhammad Rijal Assegaf yang melanjutkan khalifah tarekat Khalwatiyah Yusuf beliau mengajarkan Iman, Islam, dan 
Ihsan. Pengajaran Ihsan diajarkan melalui tarekat. Materi yang dikembangkan tarekat ini selalu bersumber dari Sunnah Rasulullah saw, dan pokok ajarannya berdasar kepada Alquran. Materi Syariah mulai dari masalah thaharah, istinja dan salat serta hukum agama lainnya. Motivasi mereka yang datang untuk bertarekat dan mengambil berkah dari ilmu tarekat. Adapun mereka yang masuk dalam tarekat ini harus mencapai usia baligh. Bagi mereka dalam sistem beragama ini harus ada seorang guru yang menuntun mereka dalam beragama. Mereka kemudian menyebut guru mereka dengan sebutan anreguru. Dengan tujuan mendapat keselamatan bersama, para murid ini merasa ada kedamaian ketika bertemu dan menjalankan ajarannnya. Datang berguru diajarkan system zikir tetapi juga diajarkan masalah syariat. Syariat tanpa tarekat kurang dan tarekat tanpa syariat adalah batal. Meskipun seorang itu mampu melakukan halhal supranatural seperti berjalan di atas air tetapi tidak melaksanakan salat hal itu adalah pekerjaan setan atau jin.

Dari segi pola pengajaran
amalan Khalwatiyah Samman
memakai zikir jahar pengucapan
wirid la ilaha illallah suara
dikeraskan anggota badan bergerak
ke kanan dan ke kiri. Gerakaan ini
diumpamakan kepada sebatang
pohon kalau diterpa angin kencang
maka daun-daunnya akan berguguran
dan bertebaran jatuh ke tanah.
Seperti juga dosa-dosa akan
berguguran.
Sedangkan Tarekat Khalwatiyah Yusuf memakai wirid dalam sistem sir merendahkan suaranya untuk tidak kedengaran terlalu keras. Menggerakkan badan secara pelan. Karena ketika menyebut nama Tuhan tidak terlalu keras suaramu dan merendahkan diri di hadapan-Nya

Adapun pendidikan pesantren yang sedang dirintis di bawah Yayasan Abdul Muthalib Assaqqaf di samping Masjid Al-Manar yang di bangun sekitar tahun 1935. Yayasan ini juga menaungi pendidikan formal yaitu Raudhatul Atfal Al-Manar yang beroperasi 10 tahun lebih di bawah ke pemimpinan Syarifah Rahmawati Asseggaf, dengan menggunakan kurikulum Kementerian Agama. Tim pengajarnya juga berasal dari Kementerian Agama.

Pesantren yang akan dibangun nantinya mempunyai ciri khas tersendiri yaitu penguatan materi pendidikan dengan muatan lokalnya yaitu pengajaran tarekat Khalwatiyah Yusuf. Tim pengajar yang sudah dipersiapkan mereka sementara belajar di pesantren Darul Lugah Wal Dakwah Pasuruan Jawa Timur mereka itu diantaranya Abdul Muthalib Assegaf, Firdaus Assegaf, dan Alwirdullatif Assegaf yang juga sementara belajar di Al-Azhar Mesir. Sebelum ke Mesir, ia masuk kepesantren Nahdatul Ulum di Barangdasi Maros, kemudian melanjutkan MAN 3 di Daya.

Keturunan Arab di Maros khususnya fam Asseggaf telah berkontribusi di lembaga ke qadhian, kemudian berafiliasi ke sistem Tarekat Khalwatiyah Yusuf. Ada pula Majelis Zikir Al-Manar yang dilakukan setiap Kamis malam yang pertemuannya dilakukan dua kali dalam satu bulan dari rumah ke rumah atau di Masjid. Untuk 
memperingati haul Puang Lallo dan puang Alwi dilaksanakan pertemuan silatuhrahmi antara anggota tarekat yang berasal dari berbagai daerah Sulawesi bahkan mereka datang dari diluar pulau Sulawesi, pada Bulan Sya'ban sebelum memasuki bulan Ramadan.

Cita cita ini umumnya mengikuti tokoh agama Islam untuk meraih kejayaan Islam dan melakukan amal jariyah di bidang pendidikan formal dan non formal. dan sebagai lembaga non formal hingga membangun lembaga formal RA Al-Manar dan sekarang merintis Pesantren Al-Manar

Keberadaan orang Arab di Maros menempati posis-posisi sentral ikut aktif di pemerintahan misalnya diantara mereka pernah menjadi staf ahli di bidang politik, Kepala Kantor Departemen Agama Maros, Ketua KPU Maros. Adapun lembaga Pendidikan keagamaaan mereka bergabung dalam lembaga formal seperti DDI dan mereka menempati posisi pucuk pimpinan. Bergabungnya mereka DDI dengan maksud kebersamaan dalam membangun lembaga itu bukan atas nama orang Arab atau pribadi.

Menurut Umi Asseggaf:

"Beberapa fam Assaggaf juga berkontribusi dalam membesarkan DDI di Maros. Dan juga berkontribusi di Sekolah Tinggi Agama Islam Maros sebagai ketuanya NU Dan MUI Maros. Kontribusi dalam lembaga itu bukan atas nama orang Arab tetapi ikut terlibat. Karena ada wadah untuk dikembangkan. Masuk dalam semua system besar dan berkontribusi walaupun bukan milik pribadi tetapi mengambil peran bersama masyarakat lokal. Dengan harapan fungsi mereka dalam menyebar agama Islam mengikuti generasi awal nenek moyang mereka berimigrasi untuk pertama kalinya dalam lembaga qadhi, tarekat, dan lembaga formal. Disamping tarekat Khawatiyah Yusuf juga mengembankan tarekat Sanusiyah (Tarikatul Muhammadiyah). Yang diterima dari mertua Muhammad Nur dan Sayid H Jamaluddin Assagaf puang Ramma. Rata-rata keluarga tarekat Muhammadiyah murid dari Muhammad Nur keturunannya di bawa kerumah beliau untuk ditalkinkan. Dan beliau menjadi muryid tarekat Nur Muhammad. Pengikutnya juga berasal dari masyarakat umum dari Makassar, Maros dan daerah lainnya.

\section{PENUTUP}

Orang-orang Arab ketika datang di suatu tempat mereka berusaha menjalin tali persaudaraan dengan penduduk lokal dengan cara kawin mawin dengan wanita setempat. Mereka kemudian membentuk pemukiman Arab di berbagai tempat di Maros seperti Labuang, Kassi, dan Pakere. Beberapa marga orang-orang Arab yang bisa terdeteksi sampai sekarang adalah Al-Hamid, Al-Idrus, AlQadri, Al-Habsyi, Bin Syihab, AlMahdali, Bil Faqih. Beberapa diantara mereka mengelola lembaga Pendidikan keagamaan di Sulawesi Selatan. Di Maros ada tarekat Khalwatiyah Yusuf mursyidnya 
adalah marga Assegaf yang tetap eksis sampai sekarang.

Menyorot keturunan Arab tersebar yang tersebar berbagai tempat di Kabupaten Maros di lembaga formal maupun non formal, mereka cukup memberikan kontribusi bagi pengembangan dunia pendidikan keagamaan. Lembaga Pendidikan keagamaan yang mereka dirikan sangat menyentuh kalangan ekonomi menengah ke bawah untuk itu perlu kiranya perhatian dari Kementerian Agama guna lebih berkembangnya lembaga-lembaga yang mereka kelola.

\section{DAFTAR PUSTAKA}

Al Alusi, Adil Muhyi Din. 1992. al Arubah wa Islam fi Januubi Syarqi Asia (al-Hind wa Induwnisiya). Diterjemahkan oleh Salim Basyarahil dengan Judul Arab Islam di Indonesia dan India. Jakarta: Gema Insani Press, 1992.

Azra, Azyumardi. 2007. Jaringan Ulama Timur Tengah dan Kepulauan Nusantara Abad XV11 dan XVIII: Akar Pembaharuan Islam Indonesia: Jakarta Kencana.

Berg, L.W.C Van Den. 2010. Orang Arab Di Nusantara.Jakarta: Komunitas Bambu.

Burhanuddin, Jajat. 2012. Ulama dan Kekuasaan Pergumulan Elite Muslim dalam Sejarah Indonesia.Jakarta: Mizan.

Darmawijaya, 2008. Nikmatnya Tasawuf Mengupas kisah Sukses Ulama Tasawuf dalam
Islamisasi

Nusantara.

Makassar: Refleksi.

Goodman J. Douglas \& Ritzer Goerge. 2007. Modern

Socioloycal Theory, 6 th Edition ( Teori Sosiologi Modern, Edisi ke-6) Jakarta: Kencana.

Hamid Abu 2005, Syekh Yusuf Makassar Seorang Ulama, Sufi dan Pejuang.Jakarta: Yayasan Obor Indonesia.

Kazhim, Musa 2012 “ Sekapur Sirih Sejarah, Alawiyin dan Perannya Dalam Dakwah Damai di Nusantara: Sebuah Komplikasi Bahan" Dalam "Peran Dakwah Damai Habaib/Alawiyin di Nusantara". Yogyakarta: Rausyan Fikr Institute.

Lauer, Robert H, 1977. Perspektif tentang Perubahan Sosial. Jakarta: Bina Aksara.

Mulyati, Sri. 2004. Tarekat-tarekat Muktabarah di Indonesia. Jakarta: Prenada Media. 